○藤木 晶子 $^{1}$

('北星学園大学短期大学部)

歩きながらスマートフォンを操作する「歩きスマホ」は，様々な事故 や他の歩行者とのトラブルの原因として，その危険性やマナーが社会問 題となっている。本研究では,「歩きスマホ」の危険性の増大を促す要因 を調べるため，車のエンジン音や走行音が聞こえる騒音環境下でスマー トフォンによる文字入力会話を行いながら歩行する状況が聴覚的注意の 反応時間及びNASA - TLXによる作業負担評価にどのような影響を及ほ すのかを検討した。

10 秒間隔の音提示についてスマホ操作条件（なし・あり）×騒音条件 （なし・あり）の被験者内 2 要因分散分析を行ったところ，スマホ条件の 主効果が有意であり，騒音条件の主効果は有意傾向となった。7 種類の 作業負担評価のうちフラストレーションに関しては交互作用効果が有意 であった。歩きながらスマホ操作を行うことは聴覚的な反応を鈍らせる とともに，交通騒音によって反応が遅延することが分かった。さらに，不 安感やイライラ, ストレスといったフラストレーションは, 騒音環境下 で歩きながらスマホ操作する場合がもっとも作業負荷が高かったことか ら，スマホ操作に騷音が加わることで作業負担は増加することが明らか となった。

\section{PI-045＼cjkstart騒音環境下の「歩きスマホ」が聴覚 的注意に及ぼす影響}

\section{PI-046＼cjkstart文章音読時の行頭の探索：改行位置 が視線移動に及ぼす影響について}

○阿部 晶子 ${ }^{1}$, 川崎 美里 2. .

(1国際医療福祉大学, ${ }^{2}$ 国際医療福祉大学病院)

キーワード：文章音読，改行，視線移動

目的

横書き文章の音読において, 改行時の視線移動は, 語末で行われる場 合よりも，改行が語中で行われる場合に，語彙に関する知識の影響を大 きく受けると推測される。本研究の目的は, 改行位置が視線移動に及ほ す影響を検討することである。

方 法

対象: 健常者 10 名 (平均 21.2 歳)。

課題：横書きの文章12種類。24行が語中条件（行頭が漢字単語の語中）, 24 行が語頭条件（行頭が漢字単語の語頭）となるように設定した。

手続き： PC モニタ $(1080 \times 1920$ pix $)$ に文章を提示し、アイトラッ カー（Tobii X3-120）を用いて音読時の視線を計測した。

結 果

正読率は平均 $99.7 \%$ であった。改行時，最初に視線が停留する位置（x

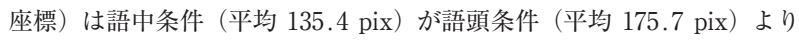
も左寄りであった $(p<.01)$ 。視線が最も左側に達する $\mathrm{x}$ 座標も，語中条 件（平均 $106.7 \mathrm{pix}$ ) と語頭条件（平均 $126.0 \mathrm{pix}$ ) で差があった $(p$ $<.01)$ 。改行時に視線が停止する回数の平均は, 語中条件が 0.00 回, 語末 条件が 0.04 回であった $(p=.054)$ 。

考 察

横書き文章の音読時, 改行が語末で行われる場合よりも, 語中で行わ れる場合に，行頭方向に視線移動が大きく行われることが示された。

連絡先 E-mail：mabe@iuhw.ac.jp

\section{PI-048＼cjkstart顔特性推論の極端さはステレオタイ プ化傾向と関連する}

○田中 千波 ${ }^{1}$

('法政大学)

顔はその人に関する様々な情報を保持する。しかし実際に顔のどのよ うな特徵が性格特性に寄与をしているのだろうか。Carré \& McCormick （2008）は facial width-to height ratio（以下, fWHR）を指標とし, 性格 特性との関連を明らかにした。しかし fWHR については未だ日本での研 究事例が不十分である。そこで本研究では先行研究の再現性を確かめる と共に, fWHR の文化的な此較を目的としている。参加者は31名であっ た。カメラを用いて顔写真を撮影し, 攻撃性, DarkTriad, TIPI-J の 3 つの質問紙に回答を求めた。fWHR の值と各質問紙の得点間の相関分析 を行った。その結果, fWHR と攻撃性 $(r=.35, p=.06)$, fWHR と Machiavellianism $(r=.37, p<.05)$ との間に相関が見られた。一方で, Psychopathy や Narcissism, TIPI-J の各項目に押いては有意な相関は見られ なかった。本研究では先行研究の再現性について改めて検討を行ったと ころ，一部支持する結果が得られた。fWHRがパーソナリティ判断の指 標の 1 つであることが示されたと同時に, fWHR という指標が日本に㧈 いても有効であることが明らかとなった。今後は, fWHRによる印象へ の影響, 及びパーソナリティとの関連について検討を行うことを想定し ている。

連絡先 E-mail：chinami.tanaka.8n@stu.hosei.ac.jp
人間は他者の顔つきを手がかりとしてその性格や能力を判断しやすい とされるが, そうした顔特性推論を実際に極端に行う程度には個人差が ある。この個人差がどのような変数と関連し，どのような原因・作用を 持つのかはまだよくわかっていない。本研究では, 顔特性推論が社会的 カテゴリーにもとづく特性推論（例えば，「笑顔の人は信頼できる」，「赤 ちゃんは無知」「「女性はか弱い」など)，つまり，ステレオタイプと密接 に関連するという指摘をもとに，カテゴリーにもとづく特性推論を極端 に行う人（ステレオタイプ化傾向の高い人）ほど極端な顔特性推論を行 うという仮説を検証した。米国人を対象としたオンライン調查（有効サ の間に中程度の正の相関が認められた $(r=.442, p<.001)$ 。両者の関連は, 任意の質問に対して社会的に望ましい選択肢を選ぶ傾向や極端な選択肢 を選ぶ傾向といった一般的な反応バイアスでは説明できないものであっ た。この結果は, 顔特性推論がステレオタイプ化傾向と結び付いている という予測を支持するものである。 ンプル数 $n=312$ ) の結果, 顔特性推論の極端さとステレオタイプ化傾向 